\title{
Revision of the family Felixaraeidae (Scleractinia; Cretaceous)
}

\author{
Hannes LÖSER \\ Estación Regional del Noroeste, Instituto de Geología, \\ Universidad Nacional Autónoma de México \\ Blvd. Luis Donaldo Colosio S/N y Madrid, Campus UNISON \\ 83250 Hermosillo, Sonora (México) \\ loeser@paleotax.de
}

KEY WORDS

Scleractinia,

Felixaraeidae, corals,

Cretaceous, new genus, new species.
Löser H. 2013. - Revision of the family Felixaraeidae (Scleractinia; Cretaceous). Geodiversitas 35 (4): 747-765. http://dx.doi.org/10.5252/g2013n4a1

\section{ABSTRACT}

The Late Cretaceous coral family Felixaraeidae (suborder Fungiina) is revised on the basis of its type genus and respective type species. The family encompasses solitary and colonial forms with very strong and perforated radial elements with a subregular radial symmetry. Radial elements are composed of large trabeculae expressed in a strongly ornamented upper septal margin and septal lateral face. Synapticulae are present. Together with the name-giving genus $\mathrm{Fe}$ lixaraea Beauvais, 1982, the Tethyan coral genera Brachycaulia Beauvais, 1982, Pseudofavia Oppenheim, 1930, and Thecoseriopsis Alloiteau, 1957, as well as the Western Atlantic genera Filkornia Löser, 2012, Paracycloseris Wells, 1934, and Trechmannaria Wells, 1935, are assigned to the family. The new genus Marcelohelia n. gen. from the Maastrichtian of Mexico is established. It differs from all known member of the family by its phaceloid growth form. All genera are revised on the basis of the types of their respective type species. Possible species of all genera are presented. The palaeobiogeography of the genera is discussed. The family occurs from the Turonian to Maastrichtian or, possible, Danian. 


\author{
MOTS CLÉS \\ Scleractinia, \\ Felixaraeidae, \\ coraux, \\ genre nouveau, \\ espèces nouvelles.
}

\section{RÉSUMÉ}

Révision de la famille des Felixaraeidae (Scleractinia; Crétacé).

Une révision de la famille des Felixaraeidae (sous-ordre des Fungiina) du Crétacé est proposée sur la base de son genre type et de son espèce type. La famille est caractérisée par de polypiers coloniaux et solitaires, avec éléments radiaires perforés et symétrie radial subrégulière. Les trabécules sont grands et les éléments radiaires montrent une ornementation forte sur leur face latérale et sur leur bord distal. La famille contient les genres Felixaraea Beauvais, 1982, Brachycaulia Beauvais, 1982, Pseudofavia Oppenheim, 1930 et Thecoseriopsis Alloiteau, 1957 de la Téthys et les genres Filkornia Löser, 2012, Paracycloseris Wells, 1934, Trechmannaria Wells, 1935 de l'Océan Atlantique de l'ouest. Le nouveau genre Marcelohelia n. gen. est décrit du Maastrichtien du Mexique. Il se distingue de tous les autres genres de la famille par la forme phacéloïde de la colonie. Tous les genres sont révisés sur la base des types de leurs espèces types. Les espèces de tous les genres sont présentées. La paléobiogéographie des genres est discutée. La distribution stratigraphique de la famille des Felixaraeidae s'étend du Turonien au Maastrichtian, peut-être jusqu'au Danien.

\section{INTRODUCTION}

The family Felixaraeidae was erected by M. Beauvais (1982) on the basis of the genus Felixaraea Beauvais, 1982, a turbinate solitary coral originally known from the Late Santonian of the Corbières mountain range (France). A short diagnosis for the family was provided by Beauvais (1982: II, 24). The family originally encompassed the genera Felixaraea, Litharaeopsis Beauvais, 1982 and Meandrophyllia d'Orbigny, 1849; Löser (2012) added the genera Paracycloseris Wells, 1934 and Pseudofavia Oppenheim, 1930 and established the new genus Filkornia. Systematic study of Late Cretaceous coral-type material revealed that the family encompasses more genera. In the present study, nine genera occurring from the Late Turonian to the ?Danian are included in the family Felixaraeidae. The temporal and spatial distribution patterns of this family shed new light on coral distribution patterns in the Late Cretaceous.

\section{MATERIAL AND METHODS}

The material comes from various localities. Most of them are listed, commented and provided with additional references in Löser et al. (2005). Only details not reported in this publication are mentioned here. If no sample number is given, the material from the locality concerned was not available for study. Each sample number refers to only one specimen.

\section{LOCALITIES}

\section{Austria}

- Oberösterreich, Gosau, Wegscheidgraben (A.576); Gosau Gp; Late Santonian. GPS FLX 1100; - Salzburg, Rußbach, Zimmergraben (A.969); Gosau Gp; Santonian. GPS FLX 8027, GPS FLX 8028; - Salzburg, St. Gilgen (A.574); Gosau Gp; Late Turonian. BSPG 1878 XI 413\#1.

\section{France}

- Aude, Les Corbières, Bugarach, field path NE Bugarach; Calcaire de Montferrand; Early Coniacian. This locality is not published and only known from recent sampling. BSPG 2003 XX 6898;

- Aude, Les Corbières, Sougraigne, Croutets (F.2120); Grès de Sougraigne with intercalated rudist limestone beds; Late Santonian. MNHN.F.R10953 and MNHN.F.R10975;

-Aude, Les Corbières, Soulatge (F.289); Marno-calcaires à Gauthiericeras; Late Coniacian. MNHN.F.R10941. 
Italy

- Puglia, Lecce, Santa Cesárea Terme (I.1077); Turonian. PU 9066.

\section{Jamaica}

- Material without locality: Campanian to Maastrichtian. USNM \#315;

- Clarendon, Grantham, Rio Minho (JA.6108);

Late Maastrichtian. USNM \#548;

- Portland, Moore Town (JA.1342); Rio Grande

Fm; Latest Campanian. NHM R30284;

- St. James, Catadupa (JA.1122); Late Maastrichtian. USNM 85834;

- St. James, Catadupa midway, Cambridge, Railway cut (JA.1341); Late Masstrichtian. USNM I-74483, I-74489;

- Westmoreland, Marchmont Inlier, Ducketts Land Settlement; Late Maastrichtian. USNM J71-128b, \#454, \#466;

- Westmoreland, Jerusalem Mt Inlier; Guinea Corn Fm; Early/Late Maastrichtian boundary. USNM \#375c, \#353, \#411, \#427;

- Westmoreland, Mint, Solomon Mt (JA.305); Maastrichtian. MCZ 114215.

\section{Mexico}

- San Luis Potosi, Arroyo de la Atarjea near Cárdenas; Upper Cárdenas Fm; Maastrichtian. For details see Schafhauser et al. (2003). IGM 8724, 8727, 8728; - Chiapas, Roadcut N Ocozocoautla; Ocozocoautla Fm; Maastrichtian. See Löser (2012) for details. ERNO L-7043.

\section{Spain}

- Cataluña, Lérida, Com. Pallars Jussà, Mun. Pallars Jussà, Pobla de Segur, S of Torallola (E.6400); Vallcarga Fm, Olistostromes of Puigmanyons Mbr; Early Late Campanian. MB K 1137.

\section{METHODS}

The present study is - as far as possible - based on type material. If thin sections could not be obtained from it, thin sections of topotypical material are used. Some of these thin sections are taken from the collection of the MNHN, where thin sections almost always have a name and a locality, but rarely a number. Thin sections were compared to types, as far as available, and to the original illustration to ensure that the examined thin sections was obtained from the type specimen. Material form the Maastrichtian of Jamaica kept at the USNM has no formerly collection numbers, here the temporary numbers found on the thin sections or with the samples are given. Localities are only partly available for these samples.

\section{ABBREVIATIONS \\ Collections}

BSPG Bayerische Staatssammlung für Paläontologie und Geologie, München;

ERNO Instituto de Geología, Estación Regional de Noroeste, Universidad Nacional Autónoma de México, Hermosillo, Sonora;

GPS Geologische und Paläontologische Sammlung der Universität Leipzig;

HUJI Hebrew University, Jerusalem;

IGM Instituto de Geología, Mexico City;

MCZ Havard University, Museum of Comparative Zoology, Cambridge;

MNHN.F Muséum national d'Histoire naturelle, Collections de Paléontologie, Paris;

NHM The Natural History Museum, London;

NHMW Naturhistorisches Museum, Wien, Austria; PU Museo di Geologia e Paleontologia dell' Università di Torino;

SMNS Staatliches Museum für Naturkunde Stuttgart;

USNM United States National Museum, Washington DC.

Dimensions of the corals

c calicular diameter;

c max larger outer calicular diameter;

c min smaller outer calicular diameter;

ccd distance between calicular centres;

cdw distance between calicular centres within calicular series;

crd distance of calicular series;

$s \quad$ number of radial elements in adult calices;

sd density of radial elements.

\section{Statistical values}

$\mathrm{n} \quad$ number of measurements;

min-max minimal and maximal measured values;

$\mu \quad$ arithmetic mean;

$\sigma \quad$ standard deviation;

$\mathrm{cv}$ coefficient of variation according to

K.Pearson;

$\mu \pm \sigma \quad$ first interval. 


\author{
Other abbreviations \\ nn no sample number; \\ (v) the material has been studied; \\ non excludes the quotation from the synonymy.
}

\title{
SYSTEMATICS
}

\section{Order SCLERACTINIA Bourne, 1900 Suborder FUNGIINA Verrill, 1870}

\section{Family FeliXARAeIDAE Beauvais, 1982}

DiAgNosis. - Corals of various organisation types (astreoid, phaceloid, solitary, thamnasterioid) with generally large calices (> $5 \mathrm{~mm}$ ). Radial elements composed of large trabeculae, with very thick septa in the first septal generations. Radial elements perforated, mainly in septa of younger generations. Septal upper border with coarse granules, septal lateral faces smooth or with thorns. Costae present. Synapticulae abundant and strong. Endotheca varies from genus to genus; it may be absent or very well developed. Columella generally present, parietal.

GENERA OF THE FAMILY. - Brachycaulia Beauvais, 1982, Cretastraea Kühn in Kühn \& Andrusov, 1930 (junior objective synonym of Pseudofavia), Felixaraea Beauvais, 1982, Filkornia Löser, 2012, Marcelohelia n. gen., Paracycloseris Wells, 1934, Pseudofavia Oppenheim, 1930, Thecoseriopsis Alloiteau, 1952, Trechmannaria Wells, 1935.

RANGE. - Late Turonian to ?Danian. The first indication (Pseudofavia paronai), dated as Turonian, is not well constrained. The last occurrence is similarly not well constrained; the family ranges into the Maastrichtian, but extension into the Danian is questionable.

\section{SYSTEMATIC POSITION}

The position of the family within the Fungiina is questionable. As mentioned by Morycowa \& Roniewicz (1995), the suborder Fungiina collects different families that are characterized only by porous radial elements and the presence of synapticulae. Fungiina sensu stricto are corals with synapticular bars (fulturae aucct.), which are found, for instance, in the Asteroseriidae and Fungiidae. Synapticular bars are absent in Felixaraeidae, and therefore the position of this family within the suborder Fungiina is preliminary.

Baron-Szabo (2008) included the family in the synonymy of the family Haplaraeidae. The Hap- laraeidae differs from the Felixaraeidae by having radial elements that are very regular in thickness (all septal generations have the same thickness) and only perforated at their inner margins (based on observations of the type of the type species, Haplaraea elegans Milaschewitsch, 1876, SMNS 21874).

\section{COMPARISON}

Very strong radial elements and the presence of synapticulae are also observed in the Late Cretaceous family Lamellofungiidae Alloiteau, 1952. The family currently encompasses only the type genus Lamellofungia Alloiteau, 1952. The genus Lamnastrea Reig-Oriol, 1997 may also belong to this family. The members of this family differ from those of the Felixaraeidae by having radial elements with spare pores at the inner margins.

\section{REMARKS}

The porosity of the radial elements appears irregular. It seem that both, older and younger septal generations are regularly perforated but the size of pores may vary within the same specimen resulting that almost compact to regularly perforated radial elements occur together. This feature can be observed in almost all specimens. Only Filkornia seems to have more compact septa.

\section{Genus Brachycaulia Beauvais, 1982}

TyPe SPECIES. - Brachycaulia jacobi Beauvais, 1982 by monotypy.

Diagnosis. - Astreoid colony with large calices. Radial elements irregularly perforated. Microstructure of large trabeculae. Radial elements in cross-section externally thick, becoming thinner towards the centre. Symmetry of radial elements is irregularly radial. Cycles of radial elements irregular, but generations can be distinguished. Septal generations differ in length and thickness. First septal generation reaches to the centre of the calice; further generations are subsequently shorter. Radial elements occasionally connected to each other. Septal upper border unknown, lateral face with thick granulae, inner margin unknown. Pali or paliform lobes absent. Costae present, nonconfluent, short. Synapticulae present, abundant. Columella unknown. Endotheca unknown. Wall absent. Coenosteum very narrow. Budding unknown, very probably extracalicinal. 
Distribution. — Late Santonian of the Western Tethys.

\section{SySTEMATIC POSITION}

Beauvais (1982) included the genera Brachyphyllia Reuss, 1854 and Brachycaulia in the family Brachyphylliidae, suborder Fungiina. Brachyphyllia is a faviid genus with compact radial elements composed of medium size trabeculae (based on the syntype NHMW 1864/0040/1305 of the type species Brachyphyllia dormitzeri Reuss, 1854).

\section{SPECIES}

Beauvais (1982) included three species: Brachycaulia felixi Beauvais, 1982, Brachycaulia glomerata (Reuss, 1854) and Brachycaulia jacobi Beauvais, 1982. Data can only be provided for the type species. Brachycaulia felixi is based on a small sample originally illustrated by Felix (1903) as Brachyphyllia haueri (Reuss, 1854) in reference to Pleurocora haueri Milne Edwards \& Haime, 1849 in Reuss (1854), for which Milne Edwards (1857) established the new species Pleurocora reussi Milne Edwards, 1857. Later, Baron-Szabo (2000) included the sample illustrated by Felix (1903) in the synonymy of Brachyphyllia felixi Baron-Szabo, 2000. Brachyphyllia felixi Baron-Szabo, 2000 is therefore a junior objective synonym of Brachycaulia felixi. The small type specimen of Brachycaulia felixi (GBA nn) shows only one calice with a polished surface. It is possibly a member of the family Felixaraeidae; however, because of its plocoid growth form and the poor knowledge of its morphology, it remains a questionable species of uncertain position. The type of Brachycaulia glomerata (NHMW 1864/0040/1306) is a well preserved but small specimen without any polished surface. Its systematic position is unknown. The radial elements are almost uniform in thickness and the ornamentation of the septal upper margin is very regular, which is also uncommon for the family Felixaraeidae.

\section{REMARKS}

The new species and genus were figured by Alloiteau (1957) but not described. Formal combined description of the genus and species is attributed to Beauvais (1982). The genus is similar to Pseudofavia but differs by having much thinner and more abundant radial elements. The type sample is not available at the MNHN; only two thin sections are available. The nature of the endotheca and the calicular centre could not be discerned from the available thin sections.

Brachycaulia jacobi Beauvais, 1982

(Fig. 2G)

Brachycaulia jacobi Beauvais, 1982: 228, II (v).

Brachycaulia Jacobi-Alloiteau 1957: pl. 2: 6, pl. 11: 2, pl. 19: 10 (v).

MATERIAL EXAMINED. — MNHN.F.R10975 (holotype) with two thin sections.

Dimensions. - c 17-18 mm, s 120.

Occurrence. - France, Aude: Les Corbières, Sougraigne, Croutets (Upper Santonian).

\section{Genus Felixaraea Beauvais, 1982}

TYPE SPECIES. - Felixaraea rennensis Beauvais, 1982 by original designation.

RANGE. - Late Turonian to Maastrichtian.

Distribution. - Western and Central Tethys and Caribbean.

Diagnosis. - Solitary cylindrical coral. Calicular outline elliptical. Radial elements regularly and moderately perforated. Microstructure of large trabeculae. Radial elements in cross-section externally thick, becoming thinner towards the centre, first generation disproportionately thicker than other generations. Symmetry of radial elements irregularly radial. Cycles of radial elements subregular. Septal generations differ in length and thickness. First septal generation reaches to the centre of the calice, further generations are subsequently shorter. Radial elements of younger generations often connected to radial elements of older ones. Septal upper border coarsely granulated, lateral face with thick granulae. Costae present, with coarse granules on their surface. Synapticulae present, abundant. Columella absent. Endotheca consists of numerous dissepiments. Wall absent. Epitheca present.

\section{SPECIES}

Currently, five species are assigned to this genus: F. gigantea (Oppenheim, 1930), F. pollicaris (Op- 
penheim, 1930), F. pratzi (Felix, 1903), F. rennensis Beauvais, 1982, and $F$. reticularis (Oppenheim, 1930). They may be partly synonymous. Leptophyllia agassizi Vaughan, 1899 is also included in this genus. Here, the various species are only distinguished on the basis of their septal numbers.

\section{REMARKS}

The type species was illustrated by Alloiteau (1952, 1957) but a description was not provided. The first valid description was provided by Beauvais (1982). The most striking feature in Felixaraed is the connection between synapticulae and perforated radial elements, appearing like long and strong apophysal septa that do not exist. The highly perforated radial elements of younger cycles receive more stability through the synapticulae.

\section{Felixaraea agassizi (Vaughan, 1899)} (Fig. 1A-C)

Leptophyllia agassizi Vaughan, 1899: 242, pl. 40, figs 1-4 (v).

Paracycloseris nariensis - Baron-Szabo 2008: 180, pl. 17, figs 7-9 [non 1-6] in part (v).

MATERIAL EXAMINED. - MCZ 114215 (holotype), USNM \#315, USNM \#375c, USNM \#427; four thin sections.

DiMENSIONS. - MCZ 114215, c 13.5-15 mm, s 192; USNM \#427, c 26-27 mm, s 192; USNM \#315, c 26$29 \mathrm{~mm}, \mathrm{~s} 192$.

OCCURRENCE. - Maastrichtian of Jamaica (Westmoreland) Mint, Solomon Mt. Early/Late Maastrichtian boundary of Jamaica (Westmoreland) Jerusalem Mt Inlier. Late Maastrichtian of Jamaica (Clarendon) Grantham, Rio Minho.

\section{Felixaraea pratzi (Felix, 1903)}

$$
\text { (Fig. 1D-F) }
$$

Haplaraea Pratzi Felix, 1903: 184, text-fig 9, pl. 17, fig. 1 (v). — Oppenheim 1930: 29, pl. 27, fig. 5 (v). Vaughan \& Wells 1943: pl. 15, fig. 4, pl. 16, fig. 9 (v). Wells 1956: 388, fig. 280.6 (v). — Beauvais 1982: (2) 25, fig. 68, pl. 23, fig. 4 (v).
Haplaraea sp. - Pratz 1882-83: 102 (v).

Haplaraea reticularis - Alloiteau 1952: pl. 2, fig. 5.

Material EXAMINED. - BSPG 1878 XI 413\#1 (syntype; one thin section), BSPG 2003 XX 6898 (one thin section), GPS FLX 8028 (two thin sections), MNHN.F.nn (one thin section).

Dimensions. - BSPG 1878 XI 413\#1, c 27-30, s 140.

OCCURRENCE. - Late Turonian of Austria (Oberösterreich) Wolfgangsee, Sankt Wolfgang; Austria (Salzburg) St. Gilgen.

Early Coniacian of France (Aude) Les Corbières, Bugarach, field path NE Bugarach. Coniacian to Early Santonian of Austria (Oberösterreich) Gosau, Edlbachgraben. Santonian of Austria (Salzburg) Rußbach, Stöcklwaldgraben; Austria (Salzburg) Rußbach, Zimmergraben. Late Santonian of France (Aude) Les Corbières, Sougraigne; France (Aude) Les Corbières, Sougraigne, Croutets.

\section{REMARKS}

Beauvais (1982) mentioned that the holotype of this species is lost. A holotype never existed; Felix (1903) mentioned various syntypes. Beauvais (1982) selected as the "neotype" a sample illustrated by Felix (1903: textfig. 9). This figure shows a magnified detail of a transversal coral section and, therefore, it cannot be attributed to any sample. Moreover, the neotype is invalid because it does not fulfil the IRZN. There is one syntype available (BSPG 1878 XI 413\#1), which is the sample that has been already studied by Pratz (1882-83) and which is also mentioned by Felix (1903).

\section{Felixaraea rennensis Beauvais, 1982}

(Fig. 1G-I)

Felixaraea rennensis Beauvais, 1982: (2), 25 (v).

Haplaraea rennensis - Alloiteau 1952: pl. 2, fig. 4, textfig. 110;1957: fig. 278-280 (v).

Phragmosmilia lineata - Baron-Szabo 1998: p. 138 (v).

Material EXAMINED. - MB K1137, GPS FLX 8027, MNHN.F.R10953 (?holotype); four thin sections.

DIMENSIONS. - MNHN.F.R10953, c 26-31, s 80; MB K1137, c 13-15.4, s 80; GPS FLX 8027, c 25-27, s 96. 

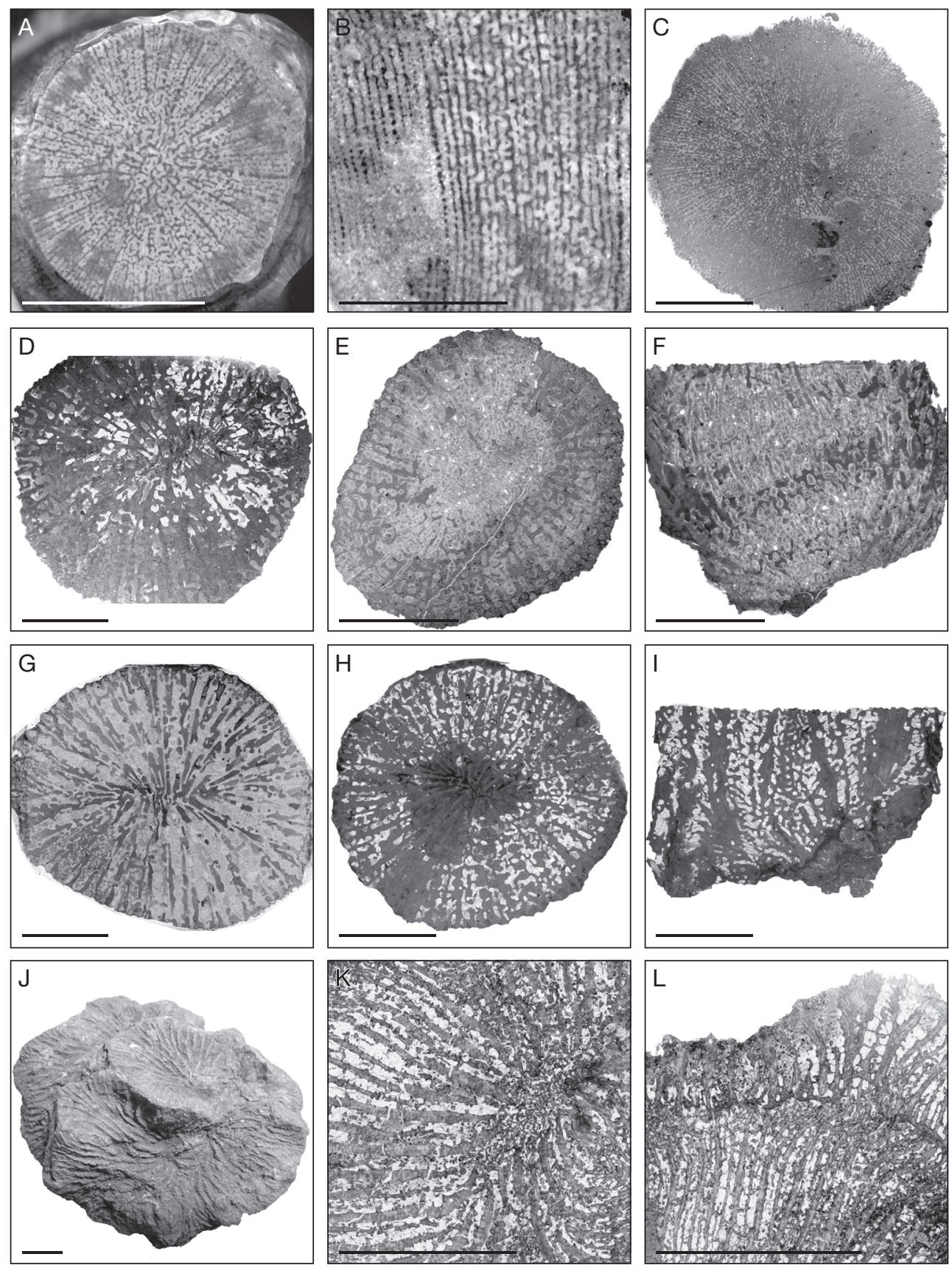

FIG. 1. - A-C, Felixaraea agassizi (Vaughan, 1899); A, B, holotype of Leptophyllia agassizi (MCZ 114215); A, transversal section. B, longitudinal section; C, USNM \#427, transversal thin section; D-F, Felixaraea pratzi (Felix, 1903); D, syntype of Haplaraea pratzi (BSPG 1878 XI 413\#1), transversal thin section; E, F, GPS FLX 8028; E, transversal thin section; F, longitudinal thin section; G-I, Felixaraea rennensis Beauvais, 1982; G, holotype of Felixaraea rennensis (MNHN.F.R10953), transversal thin section; H-I, GPS FLX 8027. H, transversal thin section; I, longitudinal thin section; J-L, Filkornia parasolitaria Löser, holotype (ERNO L-7043); J, colony surface. $\mathbf{K}$, transversal thin section; L, longitudinal thin section. Scale bars: A, C-L, $10 \mathrm{~mm}$; B, $5 \mathrm{~mm}$. 
OCCURRENCE. - Santonian of Austria (Salzburg) Rußbach, Zimmergraben. Late Santonian of France (Aude) Les Corbières, Sougraigne; Sougraigne, Croutets. Early Late Campanian of Spain (Cataluña, Lérida) Com. Pallars Jussà, Mun. Pallars Jussà, Pobla de Segur, Torallola.

\section{OTHER SPECIES}

Felixaraea reticularis (Oppenheim, 1930). The type material (HUJI 24850) was not available for study. According to Beauvais (1982), it has the following dimensions: c 18-21, s 180.

Felixaraea pollicaris (Oppenheim, 1930). The type material was not available for study; moreover, according to Beauvais (1982), it is thought to be lost. The specimen illustrated in Oppenheim (1930) is very eroded and shows approximately 120 radial elements. According to Beauvais (1982), this species is distinguished from $F$. pratzi by its smaller calicular diameter.

Felixaraea gigantea (Oppenheim, 1930). The holotype by monotypy (BSPG $1878 \mathrm{XI} 413 \# 2$ ) is (according to Oppenheim [1930]) a specimen illustrated by Felix (1903: textfig. 9, pl. 17[1b]) and was originally assigned to $H$. pratzi. Certainly, the specimen was not figured by Felix (1903) because text-figure 9 shows a detail of a transversal section, and pl. 17, figure $1 \mathrm{~b}$ shows a detail of a longitudinal section whereas the type of F. gigantea is not sectioned. Felixaraea gigantea was distinguished by Oppenheim (1930) as a new species on the basis of its large diameter and large number of radial elements (c 58-70, s 250).

Other species originally assigned by Oppenheim (1930) to Haplaraea were not considered by Beauvais (1982); they may not belong to Haplaraea (this genus did not reach the Late Cretaceous) and very probably did not belong to the Felixaraea.

\section{REMARKS}

The sample reported (but not figured) by BaronSzabo (1998) shows less perforated radial elements. The specimen MNHN.F.R10953 is not catalogued as holotype, but corresponds to the illustration in Alloiteau (1952).

\section{Genus Filkornia Löser, 2012}

TYPE SPECIES. — Filkornia parasolitaria Löser, 2012.
DiAGNOSIS. - Astreoid colony. Calices large. Radial elements regularly but not abundantly perforated. Microstructure of large trabeculae. Radial elements in cross section thick on the outside, getting thinner towards the centre. First cycles disproportionately thicker compared with younger ones. Symmetry of radial elements irregularly radial. Cycles of radial elements subregular. Septal cycles differ in length and thickness. Radial elements free. Septal upper border coarsly granulated, lateral face with numerous large thorns, inner margin slightly swollen in places. Some radial elements of the first cycle are attached to the columella. Costae present, but short, non-confluent. Synapticulae present. Columella consists of a large group of isolated trabeculae, endotheca of numerous thin tabulae. Wall compact, septothecal. Coenosteum absent. Budding intracalicinal.

RANGE. - Maastrichtian.

Distribution. - Western Atlantic.

\section{Filkornia parasolitaria Löser, 2012}

(Fig. 1J-L)

Filkornia parasolitaria Löser, 2012: 539, figs 3a-j, 4a, 6a (v).

?Trochoseris catadupensis - Wells 1934: p. 78, pl. 2, figs 9, 10. — Filkorn et al. 2005: 123, fig. 2h (v).

Trochosmilia hilli - Filkorn et al. 2005, fig. 2d (v).

Cyathoseris formosa - Baron-Szabo et al. 2006: 1041, fig. 5.7 (v).

Mycetophyllia multistellata - Baron-Szabo 2006: 42, pl. 5, fig. 5, pl. 7, figs 2, 3 (v).

\section{REMARKS}

For details compare to Löser (2012).

Genus Marcelohelia n. gen.

TyPe SPECIES. - Marcelohelia caribbiensis n. sp.

Diagnosis. - Phaceloid colony. Radial elements composed of large trabeculae, subregularly perforated, with a regular radial symmetry.

Eтymology. - After Marcel Beauvais, eminent specialist of Late Cretaceous corals, who established the family Felixaraeidae.

RANGE. - Maastrichtian.

Distribution. - Western Atlantic. 
TABLE 1. - Dimensions of Marcelohelia caribbiensis n. gen., n. sp.

\begin{tabular}{|c|c|c|c|c|c|c|}
\hline Specimen & $\mathbf{n}$ & $\min -\max$ & $\boldsymbol{\mu}$ & $\mathbf{s}$ & cv & $\mu \pm s$ \\
\hline $\begin{array}{l}\text { IGM } 8724 \text { (ho } \\
\text { c min } \\
\text { c max } \\
\text { s } \\
\text { sd }\end{array}$ & $\begin{array}{r}8 \\
8 \\
96 \\
5 / 2 \\
\end{array}$ & $\begin{array}{l}8.8-14.4 \\
9.9-15.9\end{array}$ & $\begin{array}{l}11.1 \\
12.9\end{array}$ & $\begin{array}{l}2.1 \\
2.3\end{array}$ & $\begin{array}{l}18.6 \\
17.8\end{array}$ & $\begin{array}{r}9.0-13.1 \\
10.6-15.2\end{array}$ \\
\hline $\begin{array}{l}\text { USNM \#353 } \\
\text { c min } \\
\text { c max } \\
\text { s } \\
\text { sd }\end{array}$ & $\begin{array}{r}12 \\
14 \\
96 \\
5 / 2\end{array}$ & $\begin{array}{l}10.5-14.9 \\
12.2-16.6\end{array}$ & $\begin{array}{l}12.9 \\
14.7\end{array}$ & $\begin{array}{l}1.4 \\
1.2\end{array}$ & $\begin{array}{r}10.4 \\
8.2\end{array}$ & $\begin{array}{l}11.6-14.3 \\
13.5-15.9\end{array}$ \\
\hline
\end{tabular}

\section{DESCRIPTION}

Phaceloid colony with large calices. Radial elements subregularly perforated. Microstructure of large trabeculae. Radial elements in cross-section externally thick, becoming thinner towards the centre. Symmetry of radial elements radial and regularly hexameral. Cycles of radial elements regular. Septal cycles differ in length and thickness. Radial elements occasionally connected to each other, upper border with large regular granules. Septal lateral face with thick granulae, inner margin smooth. Some radial elements may be attached to the columella. Costae present. Synapticulae present, abundant. Columella poorly defined, probably lamellar. Endotheca absent. Wall absent. Epitheca present. Budding intracalicinal, marginal.

\section{COMPARISON}

The new genus compares well to Felixaraea and Pseudofavia, but differs from these genera and all other genera of the family by its phaceloid growth form.

\section{SPECIES}

The type species and a species that is reported here in open nomenclature.

\section{Marcelohelia caribbiensis $\mathrm{n}$. sp.} (Fig. 2A-D; Table 1)

Dermosmiliopsis orbignyi-Baron-Szabo et al. 2006: 1041, fig. 5.8 (v). - Baron-Szabo 2008: 194, pl. 20: 2 (v). Non Dermosmiliopsis orbignyi Alloiteau, 1952.
Dermosmiliopsis tenuicostata - Baron-Szabo 2008: 195, pl. 20: 3 (as sample number \#535) (v). Non Rhabdophyllia tenuicosta Reuss, 1854.

TyPe MATERIAL. - IGM 8724 (holotype).

Diagnosis. - Marcelohelia n. gen. with a approximate calicular diameter of $10-15 \mathrm{~mm}$ and 96 radial elements.

MATERial eXAMined. - IGM 8724, USNM \#353; four thin sections.

ETymology. - After the distribution area, the Caribbean.

Type locality. - Arroyo de la Atarjea near Cárdenas, San Luis Potosi, Mexico.

Type Horizon. - Upper Cárdenas Fm (Maastrichtian).

OCCURRENCE. - Maastrichtian of Mexico (San Luis Potosi) Cárdenas, Arroyo de la Atarjea (IGM 8724). Early/Late Maastrichtian boundary of Jamaica (Westmoreland) Jerusalem Mt Inlier (USNM \#353).

Dimensions. - See Table 1.

\section{DESCRIPTION}

Phaceloid colony. Calicular outline circular to elliptical, diameter c. $10 \times 15 \mathrm{~mm}$, centres slightly depressed, margins elevated. Radial elements irregularly perforated. Radial elements in cross-section externally thick, becoming thinner towards the centre. Maximum septal thickness $400 \mu \mathrm{m}$. Symmetry of radial elements radial and regularly hexameral. Cycles of radial elements regular. Nine cycles $(s=96)$. Septal cycles differ in length and thickness. First three septal cycles reach to the centre of the calice, further cycles 
TABLE 2. - Dimensions of Marcelohelia sp. (USNM \#411).

\begin{tabular}{lcccccc}
\hline & $\mathbf{n}$ & $\boldsymbol{m i n}-\mathbf{m a x}$ & $\boldsymbol{\mu}$ & $\sigma$ & $\mathbf{c v}$ & $\boldsymbol{\mu} \pm \sigma$ \\
\hline $\mathrm{c} \min$ & 8 & $4.9-8.0$ & 6.3 & 1.0 & 16.4 & $5.2-7.3$ \\
$\mathrm{c} \max$ & 6 & $5.3-8.9$ & 7.1 & 1.5 & 21.8 & $5.5-8.6$ \\
$\mathrm{~s}$ & $96-120$ & & & & & \\
sd & $12 / 2.5$ & & & & & \\
\hline
\end{tabular}

are shorter. Radial elements occasionally connected to each other, upper border with large regular granules. Septal lateral face with thick granulae, inner margin smooth. Some radial elements may be attached to the columella. Costae present, nonconfluent, surface granulated. Synapticulae abundant. Columella poorly defined, probably lamellar. Endotheca absent. Wall absent. Epitheca present. Coenosteum absent. Budding intracalicinal, marginal.

\section{REMARKS}

This material was assigned by Baron-Szabo et al. (2006) and Baron-Szabo (2008) to Dermosmiliopsis orbignyi Alloiteau, 1952. Dermosmiliopsis has perforate radial elements but the radial elements are thin and are almost uniform in thickness (based on a thin section from holotype MNHN.F.R10961 of the type species of Dermosmiliopsis, Dermosmiliopsis orbignyi Alloiteau, 1952). It is unknown whether Dermosmiliopsis is a pennular or nonpennular coral. If it is pennular, it is closely related to (if not synonymous with) Latomeandra. If it is non-pennular, it is closely related to Haplaraea. The small trabeculae and the strong ornamented lateral faces rather suggest a non-pennular type. Under no circumstances does the material illustrated by Baron-Szabo (2008) belong to this genus.

Marcelohelia sp.

(Fig. 2E-F)

\section{Material EXAMINED. — USNM \#411.}

Dimensions. - See Table 2.

OCCuRREnCE. - Early/Late Maastrichtian boundary of Jamaica (Westmoreland) Jerusalem Mt Inlier (USNM \#411).

\section{REMARKS}

The only sample differs from the type species in having much smaller dimensions and a larger number of radial elements.

\section{Genus Paracycloseris Wells, 1934}

TyPe SPECIES. - Paracycloseris elizabethae Wells, 1934 by original designation.

DiAGNOSIS. - Solitary patellate coral. Calicular outline circular. Radial elements regularly perforated. Microstructure of large trabeculae. Radial elements in cross-section externally thick, becoming thinner towards the centre, first cycle disproportionately thicker than other cycles. Symmetry of radial elements radial and regularly hexameral. Cycles of radial elements regular. Septal cycles differ in length and thickness. First three septal cycles reach to the centre of the calice, further cycles are shorter. Radial elements free. Septal upper border coarsely granulated, lateral face with granules, inner margin smooth. Costae present, with granulae on their surface. Synapticulae present, abundant. Columella consists of a large group of isolated trabeculae. Endotheca unknown. Wall unknown. Epitheca present.

SPECIES. - Only the type species.

RANGE. - Late Maastrichtian. The occurrence in Cuba is stratigraphically not well constrained.

Distribution. - Western Atlantic.

\section{Paracycloseris elizabethae Wells, 1934}

(Fig. 2H, I)

Paracycloseris elizabethae Wells, 1934: 86, pl. 3, figs 5-10, pl. 5, figs 1-2 (v); 1941: 291, pl. 2, fig. 1 (v); 1956: 387, fig. 280.2 (v). - Vaughan \& Wells 1943: 135, pl. 17, fig. 6 (v).

non Paracycloseris elizabethae - Filkorn et al. 2005: 125, fig. $2 \mathrm{~K}$ (= Fungiidae indet.) (v). 

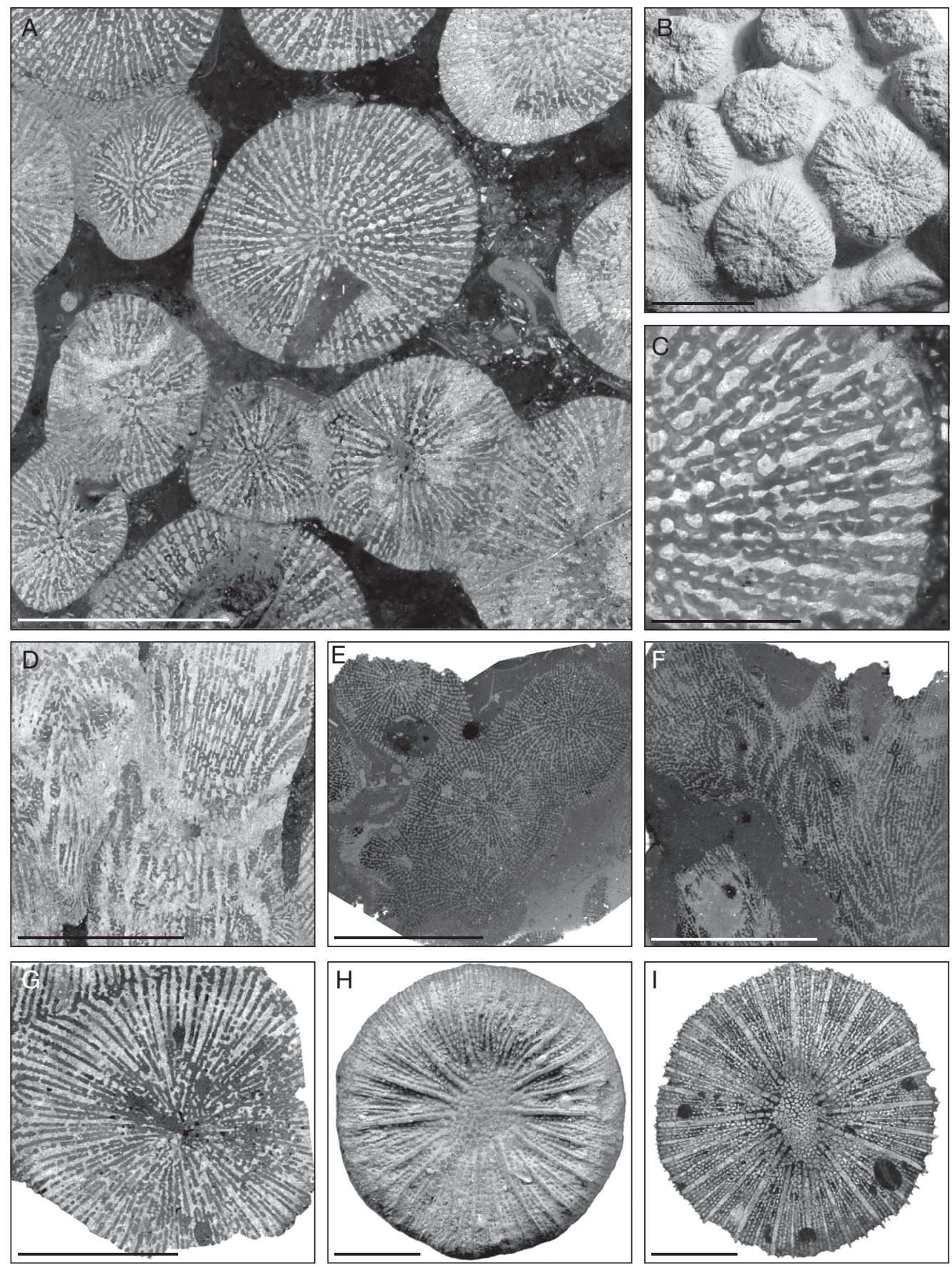

FIG. 2. - A-D, Marcelohelia caribbiensis n. gen., n. sp., holotype (IGM 8724); A, transversal thin section; B, colony surface; C, transversal thin section, detail; D, longitudinal thin section; E, F, Marcelohelia sp. (USNM \#411); E, transversal thin section; F, longitudinal thin section; G, Brachycaulia jacobi Beauvais, 1982, holotype (MNHN.F.R10975), transversal thin section; H, I, Paracycloseris elizabethae Wells, 1934; H, holotype (USNM I-74489), oral view; I, USNM J71-128b, transversal thin section. Scale bars: A, B, D-I, 10 mm; C, 3 mm. 
TABLE 3. - Dimensions of Pseudofavia paronai (Zuffardi-Comerci, 1930) (USNM I-74483).

\begin{tabular}{lccccrc}
\hline & $\mathbf{n}$ & min-max & $\boldsymbol{\mu}$ & $\sigma$ & cv & $\boldsymbol{\mu} \pm \sigma$ \\
\hline c min & 8 & $3.1-4.5$ & 3.8 & 0.5 & 13.1 & $3.3-4.3$ \\
c max & 8 & $3.6-5.2$ & 4.1 & 0.5 & 12.2 & $3.6-4.6$ \\
c cd & 11 & $4.0-5.4$ & 4.6 & 0.4 & 9.2 & $4.2-5.0$ \\
s & $48-58$ & & & & & \\
sd & $8 / 2$ & & & & & \\
\hline
\end{tabular}

Paracycloseris nariensis - Baron-Szabo 2008: 178, pl. 17, figs 1, 2 [non 3-9] in part (v). Non Trochocyathus nariensis Duncan, 1880.

MATERIAL EXAMINED. - USNM I-74489 (holotype), USNM 85834 (paratype), USNM J71-128b; one thin section.

DIMENSIONS. - USNM I-74489, c 28-29 mm, s 192; USNM 85834, c 25-26 mm, s 192; USNM J71-128b, c 27-28 mm, s 192 .

OCCURRENCE. - Late Cretaceous of Cuba (La Habana) Madruga, Esperanza 10 km E Madruga; Cuba (Las Villas) Perseverancia. Late Maastrichtian of Jamaica (Westmoreland) Ducketts Land Settlement and St. James, Catadupa.

\section{REMARKS}

In Baron-Szabo (2008), the species was included in the synonymy of Paracycloseris nariensis (Duncan, 1880), which is here ruled out (for a more detailed discussion, see Löser, 2012).

\section{Genus Pseudofavia Oppenheim, 1930}

TYPE SPECIES. - Parastrea grandiflora Reuss, 1854 by monotypy.

DiAGNOSIS. - Astreoid colony. Calicular outline polygonal to circular. Calices large. Calicular centres slightly depressed, margins elevated. Radial elements irregularly perforated. Microstructure of large trabeculae. Radial elements in cross-section externally thick, becoming thinner towards the centre. Symmetry of radial elements irregularly radial. Cycles of radial elements subregular. Septal generations differ in length and thickness. First septal generation reaches to the centre of the calice, further generations are subsequently shorter. Radial elements occasionally connected to each other, upper border with large regular granules. Septal lateral face with thick granulae, inner margin smooth. Some radial elements may be attached to the columella. Costae present, nonconfluent. Synapticulae present, abundant. Columella small, substyliform. Endotheca consists of numerous dissepiments. Wall absent. Coenosteum very narrow, consisting of large trabeculae. Budding extracalicinal.

RANGE. - Late Turonian to Santonian. The genus does not occur in the Early Cretaceous or Cenomanian. The first occurrence is not well constrained (Turonian of Italy).

Distribution. - Western and central Tethys.

\section{SPECIES}

Two species: the type species and Pseudofavia paronai (Zuffardi-Comerci, 1930). Pseudofavia andrusovi Kühn in Kühn \& Andrusov, 1930 belongs to Paraplacocoenia. Psendofavia mariae Reig Oriol, 1997 has thin compact radial elements and does not belong to this genus. Synastrea adkinsi Wells, 1934 and related material probably belong to Pseudofavia or to a new, as yet undescribed, genus.

\section{REMARKS}

Pseudofavia is not a nomen novum for Parastraea Reuss non Milne Edwards \& Haime as stated by Wells (1956: 388). Reuss never described such a genus. Oppenheim (1930) said it could be a nomen novum for Parastraea Felix, 1903, but Felix (1903) never established such a genus. Felix himself referred clearly to Reuss, who has (see above) never established such a genus. Cretastraea Kühn \& Andrusov, 1930 is a junior objective synonym.

\section{Pseudofavia grandiflora (Reuss, 1854)}

(Fig. 3A-C)

Parastraea grandiflora Reuss, 1854: 120, pl. 16, fig. 10. Felix 1903: 181, text-fig. 7. - Wells 1956: 388, fig. 280.8.

Pseudofavia grandiflora - Oppenheim 1930: 65, pl. 40, figs 5-7. — Vaughan \& Wells 1943: 133, pl. 16, fig. 10. Beauvais 1982: (2) 16, pl. 33, fig. 3. - Werner 1998: fig. 2 a. 

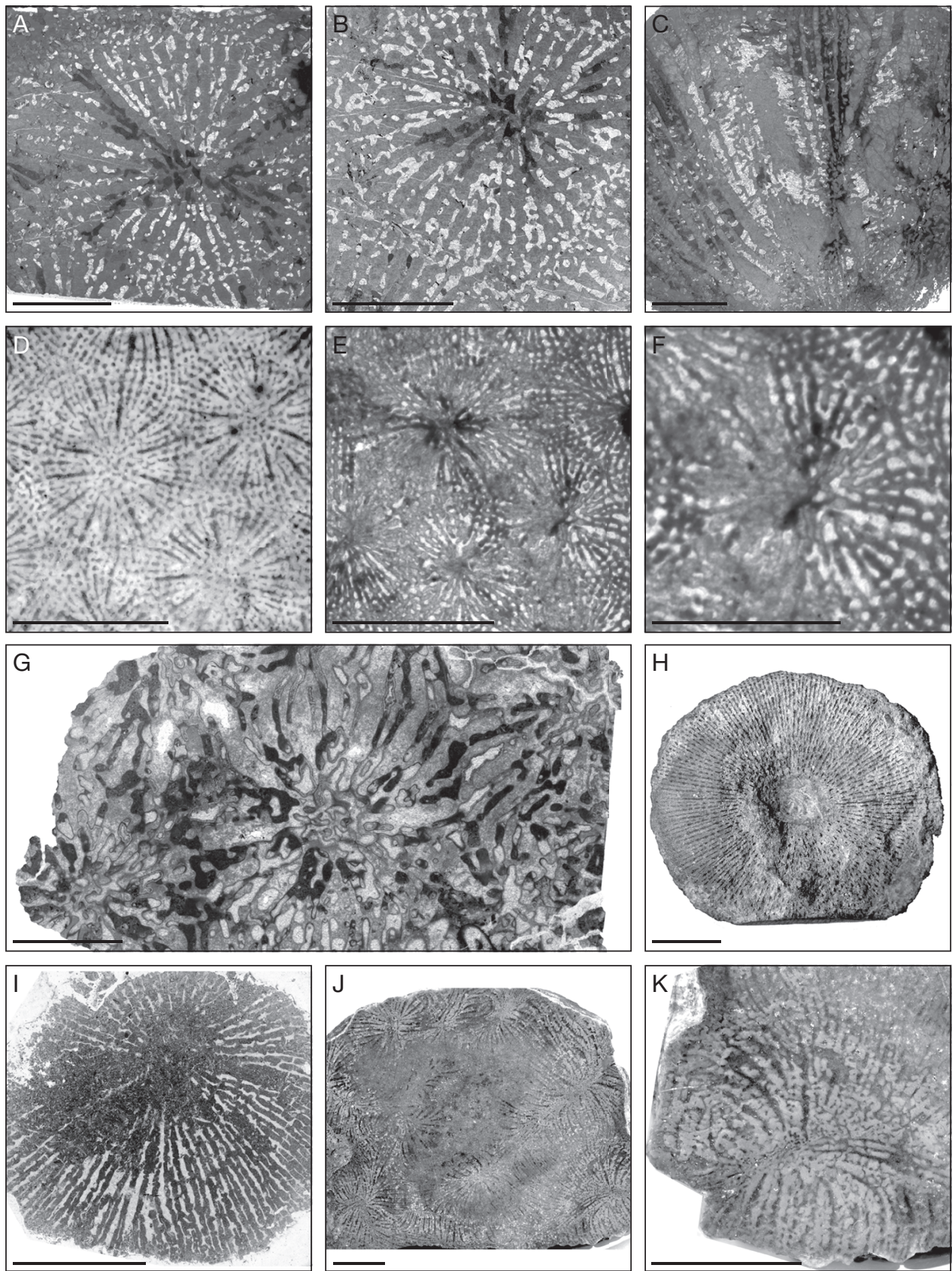

FIG. 3. - A-C, Pseudofavia grandiflora (Reuss, 1854), GPS FLX 1100; A, transversal thin section; B, transversal thin section, detail; C, longitudinal thin section; D-F, ?Pseudofavia adkinsi (Wells, 1934); D, holotype of Synastrea adkinsi Wells, 1934 (USNM I-74483) transversal slab; E, USNM \#548a, transversal thin section; F, USNM \#548a, transversal thin section, detail; G, Pseudofavia paronai (Zuffardi-Comerci, 1930), holotype of Thamnasteria paronai (PU 9066), transversal thin section; H, I, Thecoseriopsis corbariensis Alloiteau, 1952, syntypes of Thecoseriopsis corbariensis (MNHN.F.R10941); H, oral view; I, transversal thin section; J, K, Trechmannaria montanaroae Wells, 1935, Holotype of Trechmannaria montanaroae (NHM R30284); J, transversal slab; K, transversal slab, detail. Scale bars: A-C, E, H-K, $10 \mathrm{~mm}$; D, G, 5 mm; F, 3 mm. 
TABLE 4. - Dimensions of Trechmannaria montanaroae Wells, 1935 (NHM R30284).

\begin{tabular}{lcccccc}
\hline & $\mathbf{n}$ & $\min -\mathbf{m a x}$ & $\boldsymbol{\mu}$ & $\sigma$ & $\mathbf{v}$ & $\boldsymbol{\mu} \pm \sigma$ \\
\hline $\mathrm{crd}$ & 6 & $8.6-17.3$ & 13.1 & 3.7 & 28.5 & $9.4-16.8$ \\
$\mathrm{cdw}$ & $6.2-21.2$ & & & & & \\
$\mathrm{~s}$ & $60-70$ & & & & & \\
$\mathrm{sd}$ & $12 / 5$ & & & & & \\
\hline
\end{tabular}

non Parastraea grandiflora Reuss - Bendukidze 1956: 105, text-fig. 13, pl. 9, fig. 4.

non Pseudofavia grandiflora - Turnšek \& Buser 1976: 24, 45, pl. 18, figs 1-3 (v). - non Baron-Szabo 2000: 116, pl. 8, fig. 4 (v). - non Baron-Szabo 2008: 119, pl. 9 , fig. 5 (v).

Material EXAMINED. — GPS FLX 1100; 6 thin sections.

Dimensions. — c 20-22 mm, ccd 20-22 mm, sd 9/5 mm, s 36-48 (GPS FLX 1100).

Occurrence. - Coniacian to Early Santonian of Austria (Oberösterreich) Gosau, Edlbachgraben. Coniacian to Santonian of Austria (Salzburg) Rußbach, Pass Gschütt. Santonian of Austria (Oberösterreich) Gosau, Obergeschröfpalfen; Austria (Salzburg) Rußbach, Zimmergraben. Late Santonian of Austria (Oberösterreich) Gosau, Brunstloch; Austria (Oberösterreich) Gosau, Wegscheidgraben; Austria (Salzburg) Rußbach, Neffgraben.

\section{REMARKS}

The syntype of the species (NHMW 1864/0040/1395) could not be found (August 2011) in the collections of the NHMW.

\section{Pseudofavia paronai (Zuffardi-Comerci, 1930)} (Fig. 3G)

Thamnasteria paronai Zuffardi-Comerci, 1930: 22, pl. 5 , fig. 2 (v).

Material EXAMINED. — PU 9066 (holotype); 1 thin section.

Dimensions. - ccd 8-11 mm, sd 6/5 mm, s 32-36 (PU 9066).

OCCURRENCE. - Turonian of Italy (Puglia, Lecce) Santa Cesárea Terme.
?Pseudofavia adkinsi (Wells, 1934)

(Fig. 3D-F)

Synastrea adkinsi Wells, 1934: 87, pl. 3, figs 14, 15 (v). - Baron-Szabo 2008: 154, pl. 13, figs 10, 11 (v).

non Siderastrea adkinsi - Baron-Szabo et al. 2006: 1039, fig. 4.7 .

MATERIAL EXAMINED. - USNM I-74483 (holotype), USNM \#548; 1 thin section.

Dimensions. - See Table 3.

OCCURRENCE. - Late Maastrichtian of Jamaica (St. James) Catadupa and Catadupa midway, Cambridge, Railway cut; Jamaica (Clarendon) Grantham, Rio Minho.

\section{REMARKS}

The species is only known from the holotype and a thin section from topotypical material. The species (the type material as well the material illustrated by Baron-Szabo et al. 2006 and Baron-Szabo 2008) does not belong to Siderastrea as proposed by Baron-Szabo et al. (2006) and Baron-Szabo (2008) because of the strongly perforated radial elements. Siderastrea has compact radial elements which almost do not vary in thickness. The present material cannot be clearly assigned to Pseudofavia because it differs from this genus in various features: the radial elements are more strongly perforated than in Pseudofavia; the septal symmetry is regular hexameral and not irregular; the costae are confluent rather than nonconfluent; the columella is clearly parietal. The position in the genus Pseudofavia is preliminary. There is not sufficient topotypical material to establish a new genus, but there does exist more material similar to ?Pseudofavia adkinsi but showing dif- 
ferent calicular dimensions and/or septal counts (IGM 8727 and 8728 from the Maastrichtian of Mexico; USNM \#454 and \#466 from the Maastrichtian of Jamaica). Baron-Szabo (2008) mentioned and illustrated material from the Danian of Puerto Rico (USNM, Berryhill coll., PR-7 series) that may belong to this genus. This would extend the range of the family into the Danian.

\section{Genus Thecoseriopsis Alloiteau, 1952}

TYPE AND ONLY SPECIES. - Thecoseriopsis corbariensis Alloiteau, 1952 by monotypy.

DiAGNOSIS. - Solitary patellate coral. Calicular outline circular. Radial elements irregularly perforated, in cross section externally thicker, then becoming regularly thinner towards the centre. Symmetry of radial elements irregularly radial. Septal generations differ in length and thickness. First septal generation reaches to the centre of the calice, further generations are subsequently shorter. Radial elements free. Septal upper border coarsely granulated, lateral face occasionally with medium-size thorns. Costae present, with granulae on their surface. Synapticulae rare. Columella absent. Endotheca absent. Wall absent.

RANGE. - Late Coniacian.

Distribution. - Western Tethys.

Thecoseriopsis corbariensis Alloiteau, 1952 (Fig. 3H, I)

Thecoseriopsis corbariensis Alloiteau, 1952: 657; 1957: pl. 9, fig. 2 (v).

MATERIAL EXAMINED. — MNHN.F.R10941 (syntypes); 1 thin section.

Dimensions. - c 23 mm, s 192 (MNHN.F.R10941).

OCCURRENCE. - Late Coniacian of France (Aude) Les Corbières, Soulatge.

Genus Trechmannaria Wells, 1935

TYPE AND ONLY SPECIES. - Trechmannaria montanaroae Wells, 1935 by original designation.
Diagnosis. - Meandrinoid colony. Calicular rows short and straight. Calices distinct. Calicular rows wide. Radial elements perforated. Microstructure of large trabeculae. Radial elements in cross-section externally thick, becoming thinner towards the centre, first generation disproportionately thicker than other generations. Symmetry of radial elements irregularly radial. Cycles of radial elements subregular. Septal generations differ in length and thickness. First septal generation reaches to the centre of the calice, further generations are subsequently shorter. Radial elements free. Septal upper border unknown, lateral face with thorns, inner margin smooth. Costae confluent. Synapticulae abundant. Columella poorly defined, probably some granules. Valley septa present Endotheca consists of dissepiments. Wall absent. Coenosteum broad, consisting of costae. Budding intracalicinal, polystomedal, and complete.

RANGE. — Latest Campanian.

Distribution. - Western Atlantic.

Trechmannaria montanaroae Wells, 1935 (Fig. 3J, K)

Trechmannaria montanaroae Wells, 1935: 190, pl. 11, figs 2,3 (v).

Material EXAMINED. - NHM R30284 (holotype).

Dimensions. — See Table 4.

Occurrence. - Latest Campanian of Jamaica (Portland) Moore Town.

\section{OTHER MATERIAL}

The genus Litharaeopsis was assigned to the family Felixaraeidae by Beauvais (1982: II, 24). Beauvais (1982: II, 35) did assigned the genus to the family Astraraeidae. The genus Meandrophyllia d'Orbigny, 1849 was assigned to the family Felixaraeidae by Beauvais (1982), but later its position was changed and it is now assigned to the family Haplaraeidae. Meandrophyllia differs from other members of the family Felixaraeidae by septa that are thin, equal in thickness and only perforated at their inner margins. 


\section{DISCUSSION}

Comparison of the distribution of the genera of the Felixaraeidae (Fig. 4) reveals a discrepancy at the generic level between Tethyan and Western Atlantic/Caribbean shallow marine coral faunas. Each area presents its own set of genera, with the exception of the type genus, the solitary Felixaraea, that occurs in both areas. In the Tethys, restricted to the Late Turonian to Santonian, the genera Brachycaulia, Pseudofavia, and Thecoseriopsis occur. In the Western Hemisphere, from the Late Campanian and possibly into the Danian, Filkornia, Marcelohelia n. gen., Paracycloseris, and Trechmannaria occur. ?Pseudofavia adkinsi and related species from the Western Hemisphere very probably belong to a new genus. These distribution patterns call for explanation. Global palaeogeography and high sea levels during the Early Cretaceous created a world where oceans were arranged along an east-west corridor, allowing the free dispersal of marine organisms and/ or their larvae. Corals, as benthic organisms, had a cosmopolitan distribution at this time, which was primarily controlled by seawater temperature, salinity, and the type of sedimentary system. Up to the Early Cenomanian, coral faunas of the Tethys, the Western Atlantic, and the Caribbean were similar at the generic and specific level, although Atlantic and Caribbean faunas were poorer in both genera and species (Löser \& Minor 2007). For this time span, there were very few genera that were endemic to the Western Hemisphere (for instance Adkinsella, Dendroseris), whereas there were many genera that were endemic to the Tethys (for instance Aspidiscus, Clausastrea, Diplocoenia, Hydnophoromeandraraea); this is probably due to the fact that Tethyan coral faunas have been much better investigated. Endemism of coral genera during the Early Cretaceous in the Western Hemisphere is much lower than proposed, e.g., by Coates (1973).

From the Turonian on, the Tethys and the Western Hemisphere developed in different ways. The Cenomanian/Turonian boundary with Oceanic Anoxic Event 2 had a major impact on Tethyan coral faunas. Three suborders (Amphiastraeina,
Rhipidogyrina, Stylinina) and several families (Asteroseriidae, Eugyridae, Kobyastraeidae) disappeared, and many families became reduced in taxa (Elasmocoeniidae, Microsolenidae, Montlivaltidae). Faunas recovered from the Late Turonian on, but with a different inventory: the suborders Faviina and Meandrinina, and various families of other suborders (Actinacididae, Agatheliidae, Poritidae, Synastraeidae) gained diversity, including the family Felixaraeidae.

In the Western Hemisphere, as a result of the opening of the Western Interior Seaway (WIS) during the Cenomanian-Turonian, sedimentation changed from carbonate to noncarbonate (Hay 2008) and inhibited coral growth in North American and Caribbean shallow marine habitats. From the American continent and the Caribbean, corals of the Turonian to Santonian were mainly solitary (Löser et al. 2005). Some branching forms (assigned to Archohelia; Coates \& Kauffman 1973) formed small bioherms. Both solitary and branching forms also became adapted to living in a deeper marine environment. Absence of shallow marine corals can be attributed to low seawater temperature or low sea-surface salinity (Coulson et al. 2011). After the closing of the WIS during the Campanian, coral growth recovered in the Western Atlantic and the Caribbean (e.g., Texas, USA; Wells 1933) and developed rich faunas mainly during the Maastrichtian (Mexico, Jamaica, Puerto Rico; Baron-Szabo et al. 2006; Berryhill et al. 1960; Löser 2012; Stemann et al. 2007; Vaughan 1899; Wells 1934, 1935).

The taxonomic composition of Late Cretaceous coral faunas of the Tethys and that of the Western Hemisphere is difficult to compare because most Western Hemisphere faunas have not been revised (e.g. Jamaica; Netherlands Antilles; Puerto Rico; Texas, USA). The few published faunas (Baron-Szabo et al. 2006; Löser 2012) suggest at first glance that corals were still cosmopolitan during the Late Cretaceous, but more systematic comparison reveals differences at the genus and species levels. There exist various cosmopolitan genera (Actinacis, Actinastrea, Astraeofungia, Columactinastrea, Pachygyra), but there also exist many genera that are only indicated in one of the areas. 


\begin{tabular}{|c|c|c|c|c|c|c|}
\hline Distr. & Genera & TURONIAN & CONIAC. & SANT. & CAMPANIAN & MAASTRICHTIAN \\
\hline \multirow{3}{*}{ 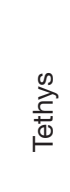 } & Brachycaulia & & & & & \\
\hline & Pseudofavia & & & & & \\
\hline & Thecoseriopsis & & & & & \\
\hline \multirow{5}{*}{ 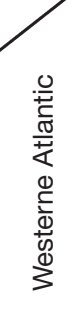 } & Felixaraea & & & & & \\
\hline & Filkornia & & & & & \\
\hline & Marcelohelia & & & & & \\
\hline & Paracycloseris & & & & & \\
\hline & Trechmannaria & & & & & \\
\hline
\end{tabular}

FIG. 4. - Stratigraphic distribution of genera of the Felixaraeidae family. Above Tethyan genera, below genera restricted to the Western Hemisphere. Only the type genus was found in both areas.

The revision of the family Felixaraeidae illustrates this. The family occurs in both areas, ranging from the Turonian to the ?Danian, but is represented by different genera in the studied areas, with the exception of the type genus.

Rapid faunal recovery after the Cenomanian was restricted to the Tethys realm; Western Atlantic and Caribbean shallow marine coral faunas, including members of Felixaraeidae, were practically non existent for about $15 \mathrm{Ma}$, but suddenly appeared with taxa different to those of Tethyan faunas in the Campanian. The genus that occurred in the Tethys realm and the Western Hemisphere, the solitary Felixaraea, occurred in the Tethys from the Late Turonian to the Early Late Campanian; in the Western Hemisphere, it is known from the Maastrichtian. This suggests that the New World Felixaraeidae family evolved from this solitary form.

\section{CONCLUSIONS}

The distribution pattern of the family Felixaraeidae calls for more investigation of coral distribution during the Late Cretaceous. Still unreported or taxonomically unrevised Late Cretaceous coral faunas from Central or South America may help to gain additional insight into the evolution and distribution of Late Cretaceous corals on a global scale and to obtain more precise data on the extinction pattern at the K/T boundary. Former studies on the subject (Baron-Szabo 2006, 2008) are based mainly on data from the existing literature; taxonomy has not been considered in detail, as the low number of illustrated thin sections shows. Future studies are needed to revise Late Cretaceous coral faunas from the Western Hemisphere, using modern methods that are able to compare Old and New World coral faunas more adequately.

\section{Acknowledgements}

I am grateful to Steven Cairns (Washington D.C.), Jessica Cundiff (Cambridge, Mass.), Jill Darrell (London), Didier Merle, Jean-Michel Pacaud, and colleagues (Paris), Arnold Müller (Leipzig), Daniele Ormezzano (Torino), and Winfried Werner (München), who allowed me to examine material from their respective museums and university collections. Study of type material was financially supported by a UNAM/DGAPA PASPA project. Reviews by Jacob Leloux (Leiden) and Elżbieta Morycowa helped to improved the paper. Grammatical correction was carried out by editage.com. 


\section{REFERENCES}

Alloiteau J. 1952. — Embranchement des coelentérés, in Piveteau J. (ed.), Traité de Paléontologie, 1. Masson, Paris: 376-684.

Alloiteau J. 1957. - Contribution à la systématique des Madréporaires fossiles. Centre national de la Recherche scientifique, Paris, 462 p.

BARON-SZABO R. C. 1998. - A new coral fauna from the Campanian of Northern Spain (Torallola village, Prov. Lleida). Geologische und Paläontologische Mitteilungen 23: 127-191.

BARON-SZABO R. C. 2000. — Late Campanian-Maastrichtian corals from the United Arab Emirates-Oman border region. Bulletin of the Natural History Museum of London (Geology) 56 (2): 91-131.

BARON-SZABO R. C. 2006. - Corals of the K/T-boundary: Scleractinian corals of the Suborders Astrocoeniina, Faviina, Rhipidogyrina, and Amphiastraeina. Journal of Systematic Palaeontology 4: 1-108.

BARON-SZABO R. C. 2008. - Corals of the K/T-boundary: Scleractinian corals of the suborders Dendrophylliina, Caryophylliina, Fungiina, Microsolenina, and Stylinina. Zootaxa 1952: 1-244.

Baron-SZabo R. C., SChafhauser A., GÖtz S. \& StinNESBECK W. 2006. - Scleractinian corals from the Cardenas Formation (Maastrichtian), San Luis Potosí, Mexico. Journal of Paleontology 80 (6): 1033-1046.

Beauvais M. 1982. - Révision systématique des Madréporaires des couches de Gosau. Comptoir géologique, Paris, 5 vols.

BENDUKIDZE N. S. 1956. - [Upper Cretaceous corals from the Godogani and Udzlouri areas.] Trudy Geologicheskogo instituta AN Gruzinskoj SSR (seriya geologiya) 9 (2): 79-125.

BerryHill H. L., Briggs R. P. \& Glover L. 1960. Stratigraphy, sedimentation, and structure of Late Cretaceous rocks in Eastern Puerto Rico - preliminary report. Bulletin of the American Association of Petroleum Geologists 44 (2): 137-155.

CoATES A. G. 1973. - Cretaceous tethyan coral-rudist biogeography related to the Evolution of the Atlantic. Special Papers in Palaeontology 12: 169-174.

Coates A. G. \& Kauffman E. G. 1973. - Stratigraphy, paleontology and paleoenvironment of a Cretaceous coral thicket, Lamy, New Mexico. Journal of Paleontology 47 (5): 953-968.

Coulson A. B., Kohn M. J. \& Barrick R. E. 2011. Isotopic evaluation of ocean circulation in the Late Cretaceous North American seaway. Nature Geoscience 4: 852-855.

FeLIX J. 1903. — Studien über die korallenführenden Schichten der oberen Kreideformation in den Alpen und den Mediterrangebieten. 1. Die Anthozoën der Gosauschichten in den Ostalpen. Palaeontographica 49: $163-360$
Filkorn H. F., Avendaño-Gil J., Coutiño-José M. A. \& Vega-Vera F. J. 2005. - Corals from the Upper Cretaceous (Maastrichtian) Ocozocoautla Formation, Chiapas, Mexico. Revista mexicana de Ciencias geológicas 22 (1): 115-128.

HAY W. W. 2008. — Evolving ideas about the Cretaceous climate and ocean circulation. Cretaceous Research 29: 725-753.

INTERNATIONAL COMMISSION ON ZOOLOGICAL NOMENCLATURE 1999. - International Code of Zoological Nomenclature. The International Trust of Zoological Nomenclature, London, $306 \mathrm{p}$.

LÖSER H. 2012. - Corals from the Maastrichtian Ocozocoautla Formation (Chiapas, Mexico) - a closer look. Revista mexicana de Ciencias geológicas 29 (3): 534-550.

LÖSER H. \& MinOR K. 2007. - Palaeobiogeographic aspects of Late Barremian to Late Albian coral faunas from Northern Mexico (Sonora) and the southern USA (Arizona, Texas). Neues Jahrbuch für Geologie und Paläontologie, Abhandlungen 245 (2): 193-218.

LÖSER H. et al. 2005. - List of Localities. Catalogue of Cretaceous Corals 3: 1-366.

Milne EdWards H. 1857. - Histoire naturelle des coralliaires ou polypes proprement dits $(1+2)$. Librairie encyclopédique de Roret, Paris: 1-326, 1-633.

MoryCOWA E. \& Roniewicz E. 1995. - Microstructural disparity between Recent fungiine and Mesozoic microsolenine scleractinians. Acta Palaeontologica Polonica 40 (4): 361-385.

Oppenheim L. P. 1930. - Die Anthozoen der Gosauschichten in den Ostalpen. Privately published, Berlin: $604 \mathrm{pp}$.

PRATZ E. 1882-83. - Über die verwandschaftlichen Beziehungen einiger Korallengattungen mit hauptsächlicher Berücksichtigung ihrer Septalstructur. Palaeontographica 29: 81-124.

REUSS A. E. 1854. - Beiträge zur Charakteristik der Kreideschichten in den Ostalpen, besonders im Gosauthale und am Wolfgangsee. Denkschriften der Kaiserlichen Akademie der Wissenschaften, Mathematisch-Physikalische Classe 7: 1-157.

Schafhauser A., Götz S., Baron-Szabo R. C. \& STINNESBECK W. 2003. — Depositional environment of coral-rudist associations in the Upper Cretaceous Cardenas Formation (Central Mexico). Geologia Croatica 56 (2): 187-198.

Stemann Th. A., Gunter G. C. \& Mitchell S. F. 2007. - ReefCoral Diversity in the Late Maastrichtian of Jamaica. Schriftenreihe der Erdwissenschaftlichen Kommissionen der Österreichischen Akademie der Wissenschaften 17: 455-469.

TuRNŠEK D. \& Buser S. 1976. - [Cnidarian fauna from the Senonian breccia of Banjški Planoti (NW Yugoslavia).] Knidarijska favna iz senonijske brece na Banjski Planoti. Razprave Slovenska akademija znanosti in umetnosti (4) 19 (3): 37-88. 
VAughan T. W. 1899. - Some Cretaceous and Eocene corals from Jamaica. Bulletin of the Museum of Comparative Zoology 34 (1): 227-250.

Vaughan T. W. \& Wells J. W. 1943. — Revision of the suborders, families and genera of Scleractinia. Special Papers. Geological Society of America 44: 1-363.

WeLlS J. W. 1933. - Corals of the Cretaceous of the Atlantic and Gulf Coastal Plains and Western Interior of the United States. Bulletins of American Paleontology 18 (67): 83-292.

WeLLS J. W. 1934. - Some fossil corals from West Indies. Proceedings of the United States National Museum 83: 71-110.

WeLLS J. W. 1935. - Corals from the Cretaceous and Eocene of Jamaica. Annals and Magazine of natural History (10) 15: 183-194.
WeLls J. W. 1941. - Upper Cretaceous corals from Cuba. Bulletins of American Paleontology 26 (97): 282-300.

Wells J. W. 1956. - Scleractinia, in Moore R. C. (ed.), Treatise on Invertebrate Paleontology, Part F. Lawrence, Kansas: F328-F444.

Werner W. 1998. — Sammlung W.Preuss: Korallen und andere Wirbellose aus den Gosauschichten (Oberkreide). Freunde der Bayerischen Staatssammlung für Paläontologie und historische Geologie München e.V. Jahresbericht und Mitteilungen 26: 22-26.

ZuFFARDI-COMERCi R. 1930. - Sulle Faune del sopracretacico in Puglia con particolare riguardo a quella di S.Cesarea. Bollettino del R. Ufficio Geologico d'Italia 55 (7): $1-35$ 